\title{
PIONEER
}

VOLUME 12, Issue 2, December 2020: 103 - 119

\section{COMPARISON OF ONLINE LEARNING EFFECTIVENESS IN THE ELE DURING COVID-19 IN MALAYSIA AND IN INDONESIA}

\author{
${ }^{1}$ Tiyas Saputri \\ ${ }^{1}$ Universitas Nahdlatul Ulama Surabaya \\ 'tiyass@unusa.ac.id \\ ${ }^{2}$ Aslam Khan Bin Samahs Khan \\ ${ }^{2}$ Erican Education College \\ ${ }^{2}$ khan8689@gmail.com \\ ${ }^{3}$ Mohammad Abdul Kafi \\ ${ }^{3}$ Universitas Nahdlatul Ulama Surabaya \\ 3mohammadabdul011.ig18@student.unusa.ac.id
}

\begin{abstract}
The Covid-19 pandemic has an impact on education. It has changed the learning system, from conventional interaction into digital interaction. The lecturers and students in Malaysia and Indonesia are required to master online learning to conduct the teaching and learning processes. However, not many lecturers apply it maximally. This study aims to find out the comparison of online learning effectiveness in English Language Education (ELE) in Malaysia and in Indonesia. This quantitative research used a questionnaire survey to collect data. The data were analyzed descriptively with tabulations and distributions of empirical data. The result reveals that $75 \%$ of Malaysian lecturers and $83 \%$ of Indonesian lecturers prefer to use synchronous learning; $25 \%$ of Malaysian lecturers and $17 \%$ of Indonesian lecturers prefer to use asynchronous learning; $65 \%$ of Malaysian students and $71 \%$ of Indonesian students prefer to use synchronous learning; 35\% of Malaysian students and 29\% of Indonesian students prefer to use asynchronous learning. For synchronous learning, 58\% of the total respondents in Malaysia like virtual meeting as an online learning tool. In Indonesia, 59\% of the total respondents like phone call as an online learning tool. For asynchronous learning, 54\% of the total respondents in Malaysia and Indonesia like blog as an online learning tool. Online learning has good effects on the English learning skills, especially listening. Academics in both countries agree that online learning is beneficial in the ELE learning and teaching process. It can be generally concluded that the use of online learning and teaching is effective in ELE.
\end{abstract}

Keywords: effectiveness, ELE, online learning, skills

\section{INTRODUCTION}

The Covid-19 pandemic has an impact on many sectors, including health, economy, and education. In education, it has also changed the learning system, which was originally conventional and monotonous; through face-to-face meeting in the classroom into an entirely digital interaction. Although digital learning has been 
heralded since the dawn of the digital era through trainings, seminars and other educational forums, not many educators apply it maximally.

The Covid-19 pandemic has made all lecturers and students in Malaysia and Indonesia learn to utilize online learning tools better. In Indonesia, citizens are advised to "Work from Home (WFH)" and practice "Social Distancing". While in Malaysia, the Malaysian government has even implemented a lockdown system (Kurnia, 2020). Nobody knows when this situation will end. This causes the lecturers and students, whether they are ready or not, to be more up to date in following the development of technology in the implementation of digital learning. Therefore, they are required to conduct online learning and teaching as the perfect solution for the teaching and learning process.

Online learning has become popular because of its potentials in providing more flexible access to contents and instructions. Online learning is where learning takes place entirely or significantly over the internet (Means, Yukie, Murphy, \& Baki, 2013). Since the online learning system has become a major priority for education system in Malaysia and Indonesia, it is essential to find out the comparison of online learning effectiveness in the ELE in Malaysia and Indonesia.

To create an effective online learning system, it is viable to investigate factors that play significant roles in its implementation. Therefore, the main objectives of this research are: 1) to identify kinds of online learning tools and examine their effectiveness in online learning of ELE in Malaysia and Indonesia; 2) to find out the students' and lecturers' responses and perceptions using online learning in ELE in Malaysia and Indonesia; 3) to assess the acquisition of English language skills using online learning in ELE in Malaysia and Indonesia; 4) to explore the comparison of online learning effectiveness in ELE in Malaysia and Indonesia.

\section{REVIEW OF LITERATURE}

The term 'online learning' (also known as 'e-learning') is used to explain the use of the internet as a technological tool that enables users to interact with the content and with other users. Besides, it also helps its users to get support during the process of learning so that they can acquire knowledge, construct personal meaning, and experience learning (Mulyono, 2020). Another definition of online learning is 
learning that takes place entirely or significantly over the internet (Means et al., 2013). Generally, online learning is a form of learning which uses internet as a tool to facilitate users in the process of learning.

Online learning has become popular because of its potential to provide more flexible access to contents, instructions, locations, and times. Means et al. (2013) mentions the benefits of online learning: (1 increasing the availability of learning experiences for learners who cannot or choose not to attend traditional face-to-face offerings, (2 assembling and disseminating instructional content more cost-efficiently, and/or (3 providing access to qualified instructors to learners in places where such instructors are not available. Online learning advocates argue that additional reasons for embracing this medium of instruction include current technology's support of a degree of interactivity, social networking, collaboration, and reflection that can enhance learning relative to normal classroom conditions (Rudestam \& Schoenholtz-Read, 2010).

There are several online learning tool categories based on Centre for Language Study, Yale University (2015): 1) audio recording and editing (Vocaroo), 2) photo editing (Pixlr), 3) multimedia projects (CLEAR's rich Internet applications), 4) collaborative working and writing (Google Docs), 5) presentation (Prezi), 6) video conferencing (Skype), 7) dictionaries and vocabulary learning (Word Reference), 8) video-production and editing (Amara), and 9) website and e-portfolios (Weebly). Furthermore, Son (2011) has made a list of online learning tools that are currently available and freely accessible on the Internet. On the basis of their main functions and features, the online learning tools are grouped into twelve categories: learning/content management systems; communication; live and virtual worlds; social networking and bookmarking; blogs and wikis; presentation; resource sharing; website creation; web exercise creation; web search engines; dictionaries and concordances; and utilities.

The use of online learning is in line with the change of the nature of English Language Education (ELE) which has transformed drastically in the last decade, even before in this Covid-19 adversity (Wong, 2013). This has not only brought a number of changes in the way English is taught and learnt, it has also led to various innovative practices around the world that is through using online learning in the ELE teaching and 
learning process, including the teaching and learning process of the four skills of English (reading, writing, listening and speaking).

There are three ways of online learning, asynchronous, synchronous and hybrid online learning. Synchronous learning is a method of learning which the attendance of a teacher and a students should be simultaneous, they should meet online on whichever platform is decided to work on, and cooperate just as they do in a classroom. Asynchronous learning is an unsynchronized method of learning, granted that the attendance of the teacher and the students can be distinct. The hybrid learning is a combination method of both synchronous and asynchronous ways of learning online (Amiti, 2020). In this research the researchers only divided the learning methods into two, synchronous and asynchronous learning methods. The Malaysian and Indonesian lecturers and students are asked about synchronous and asynchronous learning methods through questionnaire distributed via Google form.

Nowadays, the focus of interest has been more on acquiring communicative skills and improving oral proficiency. This can be achieved through web based instruction (WBI) program, which provides exposure to realistic language learning environments and thus makes the language learning more interactive and lively (Jabeen $\&$ Thomas, 2015). A language learning program based on WBI provides practice in the four language skills, reading, writing, listening and speaking. Online learning environment should be based on the following principles which have been derived from the situated learning theory: (a) provision of authentic activities within contexts, (b) benchmarking experts' thinking and performance, (c) abundant information and multiple points of view, (d) opportunity for practical reflection, (e) cooperative construction of knowledge, (f) clarification of thinking, and (g) coaching (Jabeen \& Thomas, 2015). Some researchers have reported that WBI along with computermediated communication (CMC), provides learners with rich and authentic language learning environment, and "an experience of increasing motivation, collaborative learning and social interaction which are meaningful to the learners in the language classroom" (Jabeen \& Thomas, 2015). Several researchers, however, have also raised doubts about the effectiveness of these online learning systems and have asked questions about the meaningfulness of web-based learning at all levels. According to them, not everyone involved in teaching and learning accepts the claims of the benefits, 
but rather holds a skeptical view. Such views result either due to lack of awareness of the aims and objectives of WBI, or lack of effective systems necessary for its implementation. Also, the number of research studies carried out on the effectiveness of online language learning including in the United Arab Emirates (UAE) which is quite insignificant. The students prefer classroom environment more than the online setting for language learning.

On the contrary, Rizal, Jalinus, Syahril, Sukardi, Zaus, Wulansari, \& Nabawi (2019) stated that learning in Malaysia and Indonesia has begun to integrate with ICT that implements online learning. Online learning prepares them for independent learning, lifelong learning and quality of learning. Malaysian and Indonesian lecturers and students prefer to use synchronous learning to the asynchronous one. There are a variety tools of synchronous and asynchronous learning which can be used.

Those literature reviews did not reveal any research in the Malaysia and Indonesia about the effectiveness of web based instruction or online language learning in relation to learners' overall language proficiency including the four language skills such as reading, writing, listening, and speaking at any level. Even in the other parts of the world, the available studies are limited to the effective acquisition of writing skills or reading skills in second or foreign language learning.

There is very little research done in the area of listening and oral proficiency gained through online learning systems. Jabeen \& Thomas (2015) carried out the effectiveness of online learning in United Arab Emirates (UAE) from the aspects of tools used in online learning in UAE, the effectiveness of the online learning implemented in the English classroom of UAE, the lecturers' and the students' responses to online learning and the effectiveness of learning the four important skills of reading, writing, listening and speaking. Therefore, this research is a continuing research conducted by Jabeen \& Thomas and examined the same aspects but conducted in different countries namely Malaysia and Indonesia during the Covid-19 pandemic in order to find out the comparison of online learning effectiveness in the two countries.

\section{METHOD}

The research is aimed to explore the comparison of online learning effectiveness in the ELE in Malaysia and Indonesia. This research uses a quantitative method survey. 
This quantitative method with the survey will be applied to gather the information needed. The survey which is in a form of questionnaire (Google form) is distributed through social media (whatsApp) to students and lecturers of ELE. The questionnaire contains of 22 questions. By conducting the survey through questionnaire, the current trends of tools used in online learning in Malaysia and Indonesia and the effectiveness of the online learning implementation can be explored. Besides, the difficulties and challenges learners face while learning the language online can be further explored. Simultaneously, it intends to assess the effectiveness of learning the four important skills of reading, writing, listening and speaking to understand the effective learning of each. All of these skills were assessed to see how effectively they are learnt and taught in an online setting as compared to a classroom environment.

The participants of this research are 24 Malaysian students and 18 Indonesian students. They are 18-25 years old. In addition, the participants include lecturers from educational institutions, seven Malaysian lecturers and six Indonesian lecturers. They are 30-60 years old. They live in different countries (Malaysia or Indonesia) but their institutions offer online learning during this pandemic adversity. During this time, they conduct online learning totally for ELE teaching and learning process.

The procedures of this research are:

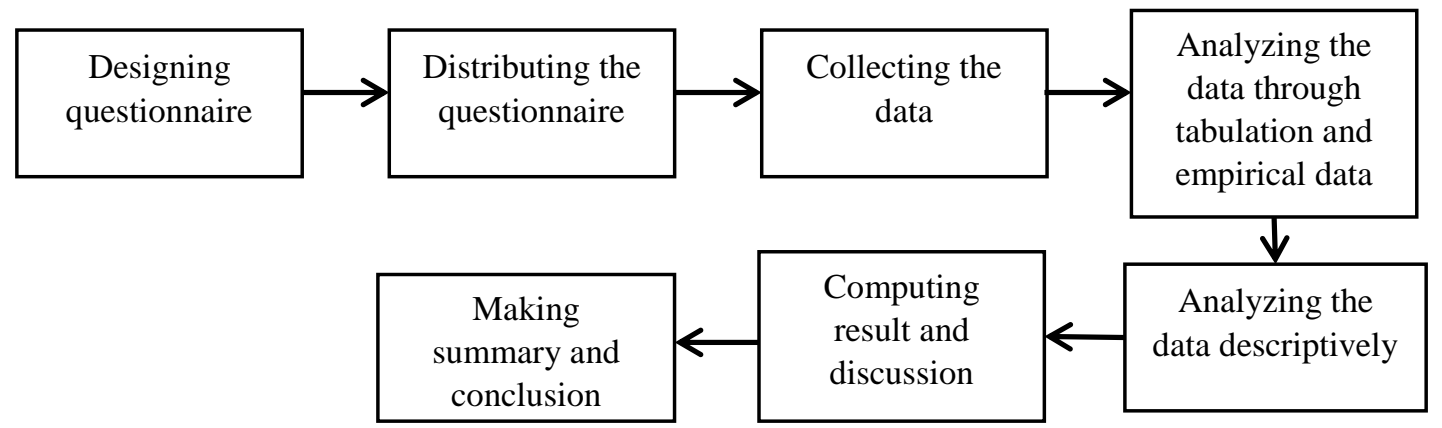

Figure 1. The procedures of the research Source: Personal Note

Based on the figure above, the first thing that the researchers do is designing questionnaire. There are 22 questions about online learning for lecturers and student in Malaysia and Indonesia. After it is ready, it is distributed to them by the team in Malaysia and Indonesia through WhatsApp mode. After it is completed by the participants of the research, the data is collected in a google spreadsheet. Next, it is analyzed through tabulation and empirical data in percentage. Then, it is analyzed 
descriptively based on the data in some tables. After the description, the result and discussion is computed. Finally, the summary and conclusion will be reached at this stage.

\section{FINDINGS AND DISCUSSION}

The findings about comparison of online learning effectiveness in the ELE during Covid-19 in Malaysia and indonesia are shown in some tables and figures below. To obtain the answer of the research questions and to assess the kinds of online tools and examine their effectiveness in online learning of ELE in Malaysia and Indonesia, the lecturers and the students for the research were given the questionnaire.

\section{Kinds of Online Tools}

Firstly, they were asked about type of online learning preferred to use whether synchronous or asynchronous learning. The findings were presented below:
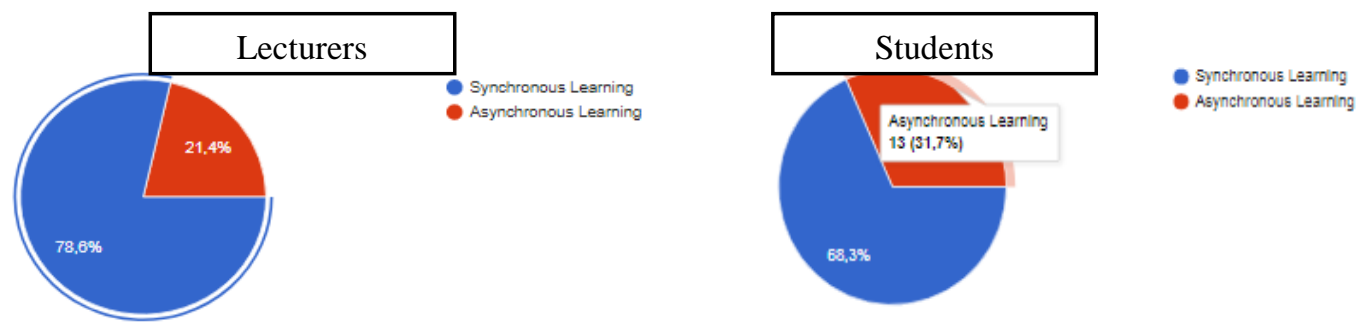

Figure 2. Type of online learning preferred to use based on Malaysian and Indonesian lecturers and students Source:

https://docs.google.com/forms/d/1I7o_VMgJIawxQyc3t2IZWgyQWDJHx9FWPGIIv05w9CQ/edit

Based on the diagram above, $78.6 \%$ of the Malaysian and Indonesian lecturers prefer to use synchronous learning, whereas, only $21.4 \%$ of them prefer to use asynchronous learning. Specifically, the comparison of types of online learning prefer to be used by lecturers and students in Malaysia and Indonesia are presented in the table below:

Table 1. Comparison of types of online learning preferred to be used by lecturers and the students in Malaysia and Indonesia

\begin{tabular}{cccccc}
\hline No & $\begin{array}{c}\text { Type of online learning } \\
\text { preferred to use }\end{array}$ & \multicolumn{2}{c}{ Average (\%) } & \multicolumn{2}{c}{ Average (\%) } \\
\cline { 3 - 6 } & & $\begin{array}{c}\text { Malaysian } \\
\text { Lecturers }\end{array}$ & $\begin{array}{c}\text { Indonesian } \\
\text { Lecturers }\end{array}$ & $\begin{array}{c}\text { Malaysian } \\
\text { Students }\end{array}$ & $\begin{array}{c}\text { Indonesian } \\
\text { Students }\end{array}$ \\
\hline $\mathbf{1}$ & Synchronous Learning & 75 & 83 & 65 & 71 \\
\hline $\mathbf{2}$ & Asynchronous Learning & 25 & 17 & 35 & 29 \\
\hline & & \multicolumn{2}{c}{ Source: }
\end{tabular}

https://docs.google.com/spreadsheets/d/1FIU8XW4rYyZQIBu1MNI1eZupMts_EbvoK3sZGutETas/edit\# gid=1807801642 
Table 1 shows that $75 \%$ of Malaysian lecturers and $83 \%$ of Indonesian lecturers prefer to use synchronous learning, whereas, $25 \%$ of Malaysian lecturers and $17 \%$ of Indonesian lecturers prefer to use asynchronous learning. Based on the table above, $65 \%$ of Malaysian students and $71 \%$ of Indonesian students prefer to use synchronous learning, whereas $35 \%$ of Malaysian students and $29 \%$ of Indonesian students prefer to use asynchronous learning. Therefore, it reveals that the Malaysian and Indonesian lecturers and students prefer to use synchronous learning to the asynchronous one.

\section{Comparison of Online Learning Effectiveness}

Table 2. Comparison of online learning tools effectiveness of synchronous learning preferred to use based on the Lecturers and the students in Malaysia and Indonesia

\begin{tabular}{|c|c|c|c|c|c|c|c|c|c|c|c|c|c|c|c|c|c|c|c|c|c|}
\hline \multirow{4}{*}{$\begin{array}{l}\mathbf{N} \\
\mathbf{0 .}\end{array}$} & \multirow{4}{*}{$\begin{array}{c}\text { Online } \\
\text { learning tools } \\
\text { of } \\
\text { Synchronous } \\
\text { Learning }\end{array}$} & \multicolumn{20}{|c|}{ The Effectiveness } \\
\hline & & \multicolumn{4}{|c|}{$\begin{array}{c}\text { Extremely } \\
\text { effective }(\%)\end{array}$} & \multicolumn{4}{|c|}{$\begin{array}{c}\text { Very } \\
\text { effective }(\%)\end{array}$} & \multicolumn{4}{|c|}{$\begin{array}{l}\text { Moderately } \\
\text { effective }(\%)\end{array}$} & \multicolumn{4}{|c|}{$\begin{array}{c}\text { Slightly } \\
\text { effective }(\%)\end{array}$} & \multicolumn{4}{|c|}{$\begin{array}{c}\text { Not at all } \\
\text { effective }(\%)\end{array}$} \\
\hline & & $\mathbf{M}$ & I & $\mathbf{M}$ & IS & $\mathbf{M}$ & I & $\mathbf{M}$ & I & $\mathbf{M}$ & I & $\mathbf{M}$ & $\mathbf{I}$ & $\mathbf{M}$ & I & $\mathbf{M}$ & I & $\mathbf{M}$ & $\mathbf{I}$ & $\mathbf{M}$ & I \\
\hline & & $\mathbf{L}$ & $\mathbf{L}$ & $\mathbf{S}$ & & $\mathbf{L}$ & $\mathbf{L}$ & $\mathbf{S}$ & $\mathbf{S}$ & $\mathbf{L}$ & $\mathbf{L}$ & $\mathbf{S}$ & $\mathbf{S}$ & $\mathbf{L}$ & $\mathbf{L}$ & $\mathbf{S}$ & $\mathbf{S}$ & $\mathbf{L}$ & $\mathbf{L}$ & $\mathbf{S}$ & $\mathbf{S}$ \\
\hline \multirow[t]{2}{*}{1} & Virtual & 0 & 17 & 11 & 4 & 1 & 5 & 2 & 3 & 7 & 3 & 4 & 3 & 0 & 0 & 0 & 1 & 1 & 0 & 6 & 4 \\
\hline & Meeting & & & & & 4 & 0 & 8 & 3 & 1 & 3 & 4 & 8 & & & & 7 & 4 & & & \\
\hline \multirow[t]{2}{*}{2} & Instant & 0 & 17 & 17 & 8 & 5 & 3 & 3 & 3 & 2 & 5 & 1 & 3 & 1 & 0 & 1 & 2 & 0 & 0 & 6 & 0 \\
\hline & Messaging & & & & & 7 & 3 & 3 & 8 & 9 & 0 & 7 & 3 & 4 & & 1 & 1 & & & & \\
\hline \multirow[t]{2}{*}{3} & Live & 0 & 17 & 22 & 17 & 4 & 3 & 2 & 3 & 6 & 2 & 3 & 2 & 0 & 1 & 1 & 1 & 0 & 0 & 0 & 4 \\
\hline & $\begin{array}{l}\text { Streaming } \\
\text { Webinar }\end{array}$ & & & & & 3 & 3 & 2 & 8 & 7 & 9 & 9 & 5 & & 7 & 1 & 7 & & & & \\
\hline \multirow[t]{2}{*}{4} & Phone Call & 29 & 33 & 17 & 8 & 2 & 6 & 2 & 2 & 4 & 0 & 3 & 5 & 0 & 0 & 1 & 1 & 0 & 0 & 0 & 0 \\
\hline & & & & & & 9 & 7 & 2 & 9 & 3 & & 9 & 0 & & & 1 & 3 & & & & \\
\hline
\end{tabular}

Source: Personal file of excel

Secondly, Malaysian and Indonesian lecturers and students were asked about online learning tools effectiveness of synchronous learning preferred to be used. Table 2 above presents the comparison of online learning tools effectiveness of synchronous learning preferred to be used by lecturers and the students in Malaysia and Indonesia. However, the researchers only emphasized on the highest percentage reached to present the most effective online learning tools of synchronous learning. For virtual meeting, $71 \%$ of Malaysian lecturers stated that it was moderately effective and $50 \%$ of Indonesian lecturers stated that it was very effective, whereas $44 \%$ of Malaysian students and $38 \%$ of Indonesian students stated that it was moderately effective. For instant messaging, there was $57 \%$ of Malaysian lecturers stated that it was very effective and $50 \%$ of Indonesian lecturers stated that it was moderately effective, whereas $17 \%$ of Malaysian students stated that it was extremely effective and moderately effective, $38 \%$ of Indonesian students stated that it was very effective. For live streaming webinar, $67 \%$ 
of Malaysian lecturers stated that it was moderately effective and 33\% of Indonesian lecturers stated that it was very effective, whereas 39\% of Malaysian students stated that it was moderately effective, $38 \%$ of Indonesian students stated that it was very effective. For phone call, $43 \%$ of Malaysian lecturers stated that it was moderately effective and $67 \%$ of Indonesian lecturers stated that it was very effective, whereas $39 \%$ of Malaysian students stated that it was moderately effective, $50 \%$ of Indonesian students stated that it was moderately effective.

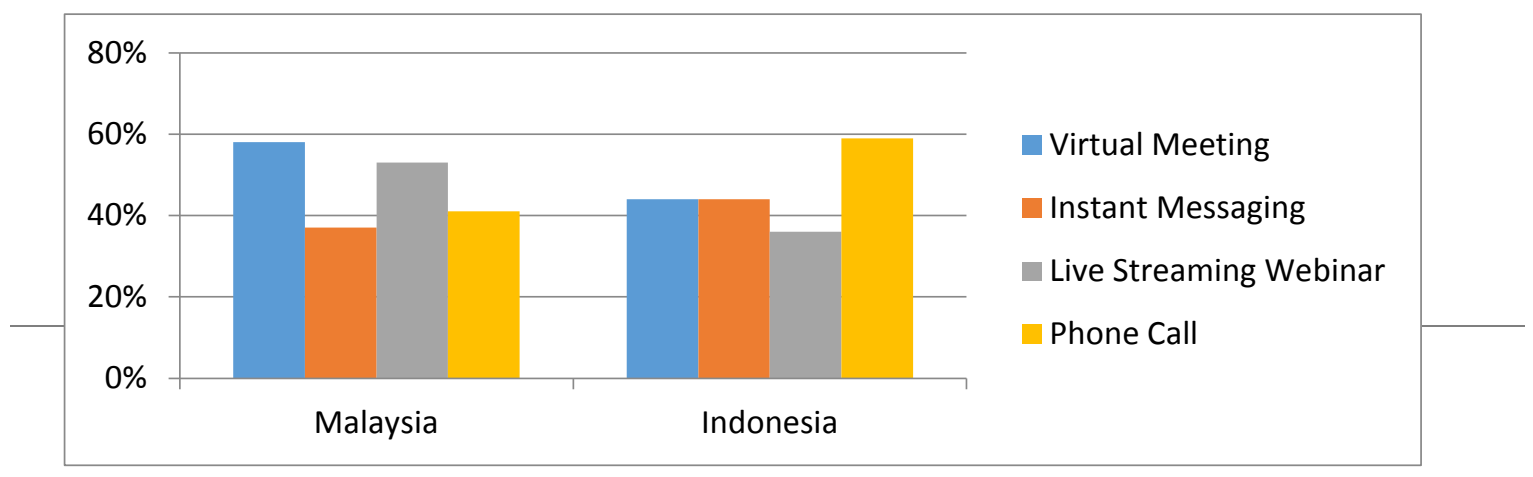

Figure 3. Comparison of online learning tools effectiveness of synchronous learning preferred to be used by lecturers and the students in Malaysia and Indonesia

Source: Personal data

Figure 3 presents Malaysian lecturer's and students' preference to use virtual meeting. Virtual meeting is in the first place (58\%), live streaming webinar is in the second place $(53 \%)$, phone call is in the third place $(41 \%)$ and instant messaging is in the fourth place (37\%). While Indonesian lecturers and students prefer to use phone call. Phone call is in the first place (59\%), virtual meeting and instant messaging is in the second place (44\%), live streaming webinar is in the third place (36\%).

Table 3. Comparison of online learning tools effectiveness of asynchronous learning preferred to use based on the lecturers and students in Malaysia and Indonesia

\begin{tabular}{|c|c|c|c|c|c|c|c|c|c|c|c|c|c|c|c|c|c|c|c|c|c|c|}
\hline \multirow{3}{*}{$\begin{array}{l}\mathbf{N} \\
\text { o. }\end{array}$} & \multirow{3}{*}{$\begin{array}{c}\text { Online } \\
\text { learning } \\
\text { tools of } \\
\text { asynchro } \\
\text { nous } \\
\text { Learnin } \\
\mathrm{g}\end{array}$} & \multicolumn{21}{|c|}{ The Effectiveness } \\
\hline & & \multicolumn{4}{|c|}{$\begin{array}{c}\text { Extremely } \\
\text { effective (\%) }\end{array}$} & \multicolumn{5}{|c|}{ Very effective (\%) } & \multicolumn{4}{|c|}{$\begin{array}{c}\text { Moderately } \\
\text { effective }(\%)\end{array}$} & \multicolumn{4}{|c|}{$\begin{array}{c}\text { Slightly effective } \\
(\%)\end{array}$} & \multicolumn{4}{|c|}{$\begin{array}{c}\text { Not at all effective } \\
(\%)\end{array}$} \\
\hline & & $\mathbf{L}$ & $\mathbf{L}$ & $\mathbf{S}$ & & $\mathbf{L}$ & & 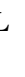 & $\mathbf{S}$ & & $\mathbf{L}$ & $\mathbf{L}$ & $\mathbf{S}$ & & $\mathbf{L}$ & $\mathbf{L}$ & $\mathbf{S}$ & & $\mathbf{L}$ & $\mathbf{L}$ & $\mathbf{S}$ & \\
\hline 1 & Email & 0 & 0 & 11 & 8 & 43 & & 5 & 22 & 3 & 14 & 1 & 3 & 3 & 29 & 1 & 1 & 4 & 14 & 1 & 0 & 8 \\
\hline \multirow[t]{2}{*}{2} & Pre- & 0 & 1 & 17 & 2 & 43 & & & 28 & 4 & 43 & 1 & 3 & 2 & 0 & 1 & 0 & 0 & 14 & 0 & 6 & 0 \\
\hline & $\begin{array}{l}\text { recording } \\
\text { video or } \\
\text { animatio } \\
n \text { video }\end{array}$ & & 7 & & 1 & & & 0 & & 2 & & 7 & 3 & 9 & & 7 & & & & & & \\
\hline 3 & $\mathrm{~B} \log$ & 0 & 0 & 6 & 4 & 29 & & & 11 & 2 & 57 & 1 & 5 & 5 & 14 & 3 & 1 & 4 & 0 & 0 & 0 & 0 \\
\hline
\end{tabular}




\begin{tabular}{|c|c|c|c|c|c|c|c|c|c|c|c|c|c|c|c|c|c|c|c|c|c|}
\hline \multirow[t]{2}{*}{4} & E-Book & 0 & 0 & 11 & 2 & 43 & 6 & 28 & 2 & 14 & 1 & 3 & 3 & 29 & 1 & 6 & 8 & 14 & 0 & 6 & 0 \\
\hline & & & & & 1 & & 7 & & 5 & & 7 & 3 & 8 & & 7 & & & & & & \\
\hline \multirow[t]{2}{*}{5} & Online & 0 & 1 & 11 & 8 & 29 & 5 & 33 & 2 & 43 & 3 & 2 & 3 & 29 & 0 & 1 & 4 & 0 & 0 & 6 & 1 \\
\hline & $\begin{array}{l}\text { forum } \\
\text { and } \\
\text { discussio } \\
\mathrm{n} \text { board }\end{array}$ & & 7 & & & & 0 & & 9 & & 3 & 2 & 8 & & & 1 & & & & & 3 \\
\hline \multirow[t]{2}{*}{6} & Online & 0 & 1 & 17 & 1 & 43 & 5 & 17 & 2 & 43 & 3 & 3 & 3 & 0 & 0 & 1 & 1 & 14 & 0 & 6 & 0 \\
\hline & course & & 7 & & 3 & & 0 & & 5 & & 3 & 3 & 8 & & & 1 & 7 & & & & \\
\hline
\end{tabular}

Source: Personal data of excel

Thirdly, Malaysian and Indonesian lecturers and students were asked about online learning tools effectiveness of asynchronous learning preferred to be used. The table 3 presents the comparison of online learning tools effectiveness of asynchronous learning preferred to be used by lecturers and the students in Malaysia and Indonesia. However, the researchers only highlighted the highest percentage reached to present the most effective online learning tools of synchronous learning. For email, $43 \%$ of Malaysian lecturers stated that it was very effective and 50\% of Indonesian lecturers stated that it was very effective, whereas $33 \%$ of Malaysian students stated that it was moderately effective and $38 \%$ of Indonesian students stated that it was very effective. For pre-recording video or animation video, $43 \%$ of Malaysian lecturers stated that it was extremely effective and very effective and $50 \%$ of Indonesian lecturers stated that it was very effective, whereas $33 \%$ of Malaysian students stated that it was moderately effective, $42 \%$ of Indonesian students stated that it was very effective. For blog, $57 \%$ of Malaysian lecturers stated that it was moderately effective and $50 \%$ of Indonesian lecturers stated that it was very effective, whereas $50 \%$ of Malaysian students stated that it was moderately effective, $58 \%$ of Indonesian students stated that it was moderately effective. For e-book, $43 \%$ of Malaysian lecturers stated that it was very effective and $67 \%$ of Indonesian lecturers stated that it was very effective, whereas $33 \%$ of Malaysian students stated that it was moderately effective, $38 \%$ of Indonesian students stated that it was moderately effective. For online forum and discussion board, $43 \%$ of Malaysian lecturers stated that it was moderately effective and 50\% of Indonesian lecturers stated that it was very effective, whereas $33 \%$ of Malaysian students stated that it was moderately effective, $38 \%$ of Indonesian students stated that it was moderately effective. For online course, $43 \%$ of Malaysian lecturers stated that it was very effective and moderately effective and $50 \%$ of Indonesian lecturers stated that it was very effective, whereas $33 \%$ of Malaysian students stated that it was moderately effective, $38 \%$ of Indonesian students stated that it was moderately effective. 


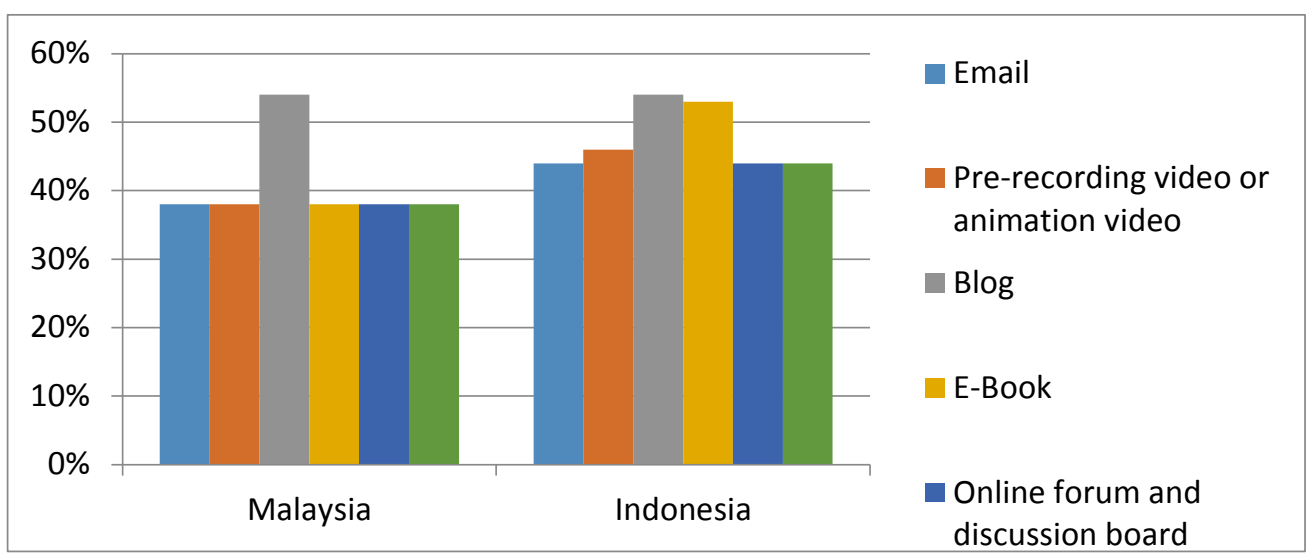

Figure 4. Comparison of online learning tools effectiveness of asynchronous learning preferred to be used by Lecturers and students in Malaysia and Indonesia Source: Personal data of Excel

Figure 4 presents Malaysian lecturers and students preference to use blog. Blog is in the first place (54\%), while other tools are in the second place $(38 \%)$. In another side, Indonesian lecturers and students prefered to use blog. Blog is in the first place (54\%), e-book is in the second place (53\%), pre-recording video or animation video is in the third place (46\%). Email, online forum and discussion board and online course are in the fourth place (44\%).

\section{Acquisition of English Language Skills Using Online Learning}

Table 4. Comparison of the effectiveness of using online learning in English skills by lecturers and students in Malaysia and Indonesia

\begin{tabular}{|c|c|c|c|c|c|c|c|c|c|c|c|c|c|c|c|c|c|c|c|c|c|}
\hline \multirow{3}{*}{$\begin{array}{l}\mathbf{N} \\
\mathbf{o .}\end{array}$} & \multirow{3}{*}{$\begin{array}{c}\mathrm{Ki} \\
\text { nds } \\
\text { of } \\
\text { En } \\
\text { glis } \\
\text { h } \\
\text { skil } \\
1\end{array}$} & \multicolumn{20}{|c|}{ The Effectiveness } \\
\hline & & \multicolumn{4}{|c|}{$\begin{array}{c}\text { Extremely effective } \\
(\%)\end{array}$} & \multicolumn{4}{|c|}{ Very effective (\%) } & \multicolumn{4}{|c|}{$\begin{array}{c}\text { Moderately effective } \\
(\%)\end{array}$} & \multicolumn{4}{|c|}{$\begin{array}{c}\text { Slightly effective } \\
(\%)\end{array}$} & \multicolumn{4}{|c|}{$\begin{array}{c}\text { Not at all effective } \\
(\%)\end{array}$} \\
\hline & & $\begin{array}{l}\mathrm{M} \\
\mathrm{L}\end{array}$ & IL & $\begin{array}{l}\mathrm{M} \\
\mathrm{S}\end{array}$ & IS & $\begin{array}{l}\mathrm{M} \\
\mathrm{L}\end{array}$ & IL & $\begin{array}{l}\mathrm{M} \\
\mathrm{S}\end{array}$ & IS & $\begin{array}{l}\mathrm{M} \\
\mathrm{L}\end{array}$ & $\mathrm{IL}$ & $\begin{array}{c}\mathrm{M} \\
\mathrm{S}\end{array}$ & IS & $\begin{array}{l}\mathrm{M} \\
\mathrm{L}\end{array}$ & IL & $\begin{array}{c}\mathrm{M} \\
\mathrm{S}\end{array}$ & IS & $\begin{array}{l}M \\
\mathrm{~L}\end{array}$ & $\mathrm{IL}$ & $\begin{array}{l}\mathrm{M} \\
\mathrm{S}\end{array}$ & IS \\
\hline 1 & $\begin{array}{l}\mathrm{Re} \\
\text { adi } \\
\mathrm{ng}\end{array}$ & 0 & 17 & 22 & 4 & 29 & 33 & 28 & 38 & 43 & 50 & 39 & 50 & 14 & 0 & 6 & 8 & 14 & 0 & 0 & 0 \\
\hline 2 & $\begin{array}{l}\mathrm{Wr} \\
\text { itin } \\
\mathrm{g}\end{array}$ & 0 & 17 & 11 & 4 & 14 & 33 & 39 & 33 & 71 & 50 & 33 & 46 & 0 & 0 & 11 & 17 & 14 & 0 & 6 & 0 \\
\hline 3 & $\begin{array}{l}\text { Lis } \\
\text { ten } \\
\text { ing }\end{array}$ & 0 & 17 & 17 & 4 & 14 & 33 & 44 & 50 & 71 & 50 & 33 & 29 & 0 & 0 & 6 & 17 & 14 & 0 & 0 & 0 \\
\hline 4 & $\begin{array}{l}\text { Sp } \\
\text { eak } \\
\text { ing }\end{array}$ & 0 & 17 & 11 & 8 & 29 & 50 & 33 & 29 & 43 & 0 & 22 & 42 & 0 & 17 & 17 & 17 & 29 & 17 & 11 & 4 \\
\hline
\end{tabular}

Source: Personal data of excel

Table 4 presented the comparison of the effect of using online learning in English skills based on the lecturers and the students in Malaysia and Indonesia. However, the researchers only emphasized the highest percentage reached to present the most effective effect of using online learning in English skills. For reading skill, $43 \%$ of 
Malaysian lecturers stated that it was moderately effective and 50\% of Indonesian lecturers stated that it was moderately effective, whereas $39 \%$ of Malaysian students and $50 \%$ of Indonesian students stated that it was moderately effective. For writing skill, $71 \%$ of Malaysian lecturers stated that it was moderately effective and $50 \%$ of Indonesian lecturers stated that it was moderately effective, whereas 39\% of Malaysian students stated that it was very effective, $46 \%$ of Indonesian students stated that it was moderately effective. For listening $71 \%$ of Malaysian lecturers stated that it was moderately effective and $50 \%$ of Indonesian lecturers stated that it was moderately effective, whereas $44 \%$ of Malaysian students stated that it was very effective, $50 \%$ of Indonesian students stated that it was very effective. For speaking skill, $43 \%$ of Malaysian lecturers stated that it was moderately effective and 50\% of Indonesian lecturers stated that it was very effective, whereas $33 \%$ of Malaysian students stated that it was very effective, $42 \%$ of Indonesian students stated that it was moderately effective.

Figure 5. Comparison of the effect of using online learning in English skills by lecturers and students in Malaysia and Indonesia

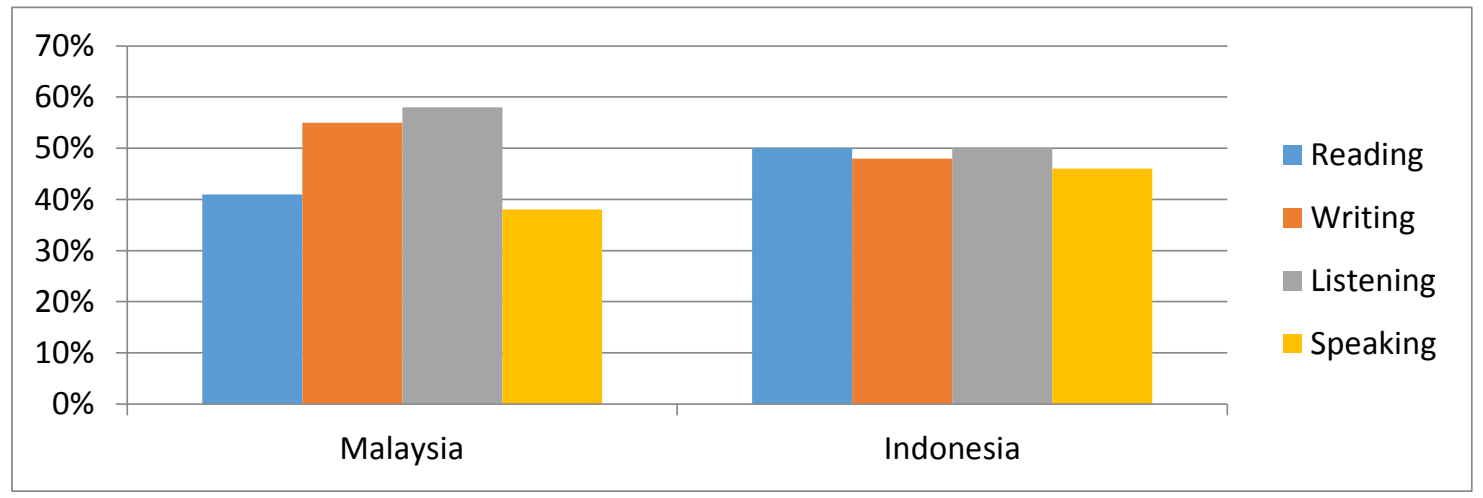

Source: Personal data of excel

Figure 5 presents the effect of using online learning in English skills by lecturers and students in Malaysia which shows that the first place is listening (58\%), the second place is writing $(55 \%)$, the third place is reading $(41 \%)$ and the fourth place is speaking (38\%). On the contrary, the effect of using online learning in English skills by lecturers and students in Indonesia which shows that the first place is listening and reading (50\%), the second place is writing (48\%), the third place is speaking (46\%). 


\section{Students' and Lecturers' Responses to Online Learning}

Table 5. Comparison of Lecturers' and Students' Responses Using Online Learning in English Language Education (ELE) in Malaysia and Indonesia

\begin{tabular}{|c|c|c|c|c|c|c|c|c|c|c|c|c|c|c|c|c|c|c|c|c|c|}
\hline \multirow{4}{*}{$\begin{array}{l}\mathrm{N} \\
\mathrm{o}\end{array}$} & \multirow{4}{*}{ Statement } & \multicolumn{20}{|c|}{ Scale of Agreement } \\
\hline & & \multicolumn{4}{|c|}{$\begin{array}{c}\text { Strongly } \\
\text { Agree (\%) }\end{array}$} & \multicolumn{4}{|c|}{ Agree $(\%)$} & \multicolumn{4}{|c|}{ Neutral (\%) } & \multicolumn{4}{|c|}{ Disagree $(\%)$} & \multicolumn{4}{|c|}{$\begin{array}{c}\text { Strongly } \\
\text { Disagree }(\%)\end{array}$} \\
\hline & & $\mathrm{M}$ & I & $\mathrm{M}$ & $\mathrm{I}$ & M & I & $\mathrm{M}$ & I & $\mathrm{M}$ & I & 1 & $\mathrm{I}$ & $\mathrm{M}$ & I & $\mathrm{M}$ & $\mathrm{I}$ & $\mathrm{M}$ & I & $\mathrm{M}$ & I \\
\hline & & $\mathrm{L}$ & $\mathrm{L}$ & $\mathrm{S}$ & $\mathrm{S}$ & $\mathrm{L}$ & $\mathrm{L}$ & $\mathrm{S}$ & $\mathrm{S}$ & $\mathrm{L}$ & L & $s$ & $\mathrm{~S}$ & $\mathrm{~L}$ & $\mathrm{~L}$ & $\mathrm{~S}$ & $\mathrm{~S}$ & $\mathrm{~L}$ & $\mathrm{~L}$ & $\mathrm{~S}$ & $\mathrm{~S}$ \\
\hline 1 & $\begin{array}{l}\text { There are } \\
\text { means to } \\
\text { interact } \\
\text { with the } \\
\text { colleagues } \\
\text { through } \\
\text { online }\end{array}$ & $\begin{array}{l}4 \\
3\end{array}$ & $\begin{array}{l}5 \\
0\end{array}$ & $\begin{array}{l}3 \\
3\end{array}$ & 8 & $\begin{array}{l}4 \\
3\end{array}$ & $\begin{array}{l}3 \\
3\end{array}$ & $\begin{array}{l}2 \\
8\end{array}$ & $\begin{array}{l}6 \\
7\end{array}$ & $\begin{array}{l}1 \\
4\end{array}$ & $\begin{array}{l}1 \\
7\end{array}$ & 3 & $\begin{array}{l}2 \\
1\end{array}$ & 0 & 0 & 6 & 4 & 0 & 0 & 0 & 0 \\
\hline 2 & $\begin{array}{l}\text { The use of } \\
\text { videos and } \\
\text { animations } \\
\text { has } \\
\text { increased } \\
\text { the amount } \\
\text { of } \\
\text { informatio } \\
\mathrm{n} \text { taught. }\end{array}$ & $\begin{array}{l}1 \\
4\end{array}$ & $\begin{array}{l}5 \\
0\end{array}$ & $\begin{array}{l}2 \\
8\end{array}$ & $\begin{array}{l}1 \\
3\end{array}$ & $\begin{array}{l}5 \\
7\end{array}$ & $\begin{array}{l}3 \\
3\end{array}$ & $\begin{array}{l}5 \\
6\end{array}$ & $\begin{array}{l}6 \\
7\end{array}$ & $\begin{array}{l}2 \\
9\end{array}$ & $\begin{array}{l}1 \\
7\end{array}$ & 7 & $\begin{array}{l}2 \\
1\end{array}$ & 0 & 0 & 0 & 0 & 0 & 0 & 0 & 0 \\
\hline 3 & $\begin{array}{l}\text { There } \\
\text { should be } \\
\text { more } \\
\text { support } \\
\text { materials } \\
\text { taught like } \\
\text { kahoot, } \\
\text { menti, } \\
\text { quizzes, } \\
\text { etc. }\end{array}$ & $\begin{array}{l}1 \\
4\end{array}$ & $\begin{array}{l}5 \\
0\end{array}$ & $\begin{array}{l}5 \\
6\end{array}$ & $\begin{array}{l}3 \\
3\end{array}$ & $\begin{array}{l}7 \\
1\end{array}$ & $\begin{array}{l}3 \\
3\end{array}$ & $\begin{array}{l}2 \\
8\end{array}$ & $\begin{array}{l}4 \\
6\end{array}$ & $\begin{array}{l}1 \\
4\end{array}$ & $\begin{array}{l}1 \\
7\end{array}$ & 1 & $\begin{array}{l}2 \\
1\end{array}$ & 0 & 0 & 0 & 0 & 0 & 0 & 0 & 0 \\
\hline 4 & $\begin{array}{l}\text { There are } \\
\text { means to } \\
\text { interact } \\
\text { with } \\
\text { students } \\
\text { through } \\
\text { online. }\end{array}$ & $\begin{array}{l}1 \\
4\end{array}$ & $\begin{array}{l}6 \\
7\end{array}$ & $\begin{array}{l}2 \\
8\end{array}$ & $\begin{array}{l}1 \\
3\end{array}$ & $\begin{array}{l}7 \\
1\end{array}$ & $\begin{array}{l}1 \\
7\end{array}$ & $\begin{array}{l}5 \\
6\end{array}$ & $\begin{array}{l}5 \\
8\end{array}$ & $\begin{array}{l}1 \\
4\end{array}$ & $\begin{array}{l}1 \\
7\end{array}$ & 1 & $\begin{array}{l}2 \\
1\end{array}$ & 0 & 0 & 0 & 4 & 0 & 0 & 6 & 0 \\
\hline 5 & $\begin{array}{l}\text { I can } \\
\text { communic } \\
\text { ate with } \\
\text { my } \\
\text { students } \\
\text { face to } \\
\text { face. }\end{array}$ & $\begin{array}{l}1 \\
4\end{array}$ & $\begin{array}{l}6 \\
7\end{array}$ & $\begin{array}{l}2 \\
2\end{array}$ & $\begin{array}{l}2 \\
9\end{array}$ & $\begin{array}{l}7 \\
1\end{array}$ & $\begin{array}{l}1 \\
7\end{array}$ & $\begin{array}{l}5 \\
0\end{array}$ & $\begin{array}{l}5 \\
0\end{array}$ & $\begin{array}{l}1 \\
4\end{array}$ & $\begin{array}{l}1 \\
7\end{array}$ & 2 & $\begin{array}{l}1 \\
3\end{array}$ & 0 & 0 & 0 & 8 & 0 & 0 & 6 & 0 \\
\hline 6 & $\begin{array}{l}\text { I am web } \\
\text { proficient. }\end{array}$ & 0 & $\begin{array}{l}3 \\
3 \\
\end{array}$ & $\begin{array}{l}1 \\
1 \\
\end{array}$ & 0 & $\begin{array}{l}5 \\
7 \\
\end{array}$ & $\begin{array}{l}1 \\
7 \\
\end{array}$ & $\begin{array}{l}2 \\
8 \\
\end{array}$ & $\begin{array}{l}3 \\
8 \\
\end{array}$ & $\begin{array}{l}2 \\
9 \\
\end{array}$ & 5 & 9 & $\begin{array}{l}5 \\
4 \\
\end{array}$ & $\begin{array}{l}1 \\
4 \\
\end{array}$ & 0 & $\begin{array}{l}1 \\
1 \\
\end{array}$ & 4 & 0 & 0 & 6 & 4 \\
\hline 7 & $\begin{array}{l}\text { My } \\
\text { students } \\
\text { are web } \\
\text { proficient. }\end{array}$ & 0 & $\begin{array}{l}3 \\
3\end{array}$ & $\begin{array}{l}1 \\
7\end{array}$ & 8 & $\begin{array}{l}7 \\
1\end{array}$ & $\begin{array}{l}5 \\
0\end{array}$ & 6 & $\begin{array}{l}3 \\
8\end{array}$ & $\begin{array}{l}1 \\
4\end{array}$ & $\begin{array}{l}1 \\
7\end{array}$ & 7 & $\begin{array}{l}5 \\
4\end{array}$ & $\begin{array}{l}1 \\
4\end{array}$ & 0 & $\begin{array}{l}1 \\
1\end{array}$ & 0 & 0 & 0 & 0 & 0 \\
\hline
\end{tabular}


Table 5 presents the comparison of lecturers' and students' responses using online learning in English Language Education (ELE) in Malaysia and Indonesia. However, the researchers only highlighted the highest percentage reached to present the most effective of using online learning in English Language Education (ELE) in Malaysia and Indonesia. For statement 1, 43\% of Malaysian lecturers stated strongly agree and agree with that statement and 50\% of Indonesian lecturers stated that strongly agree with it, whereas $33 \%$ of Malaysian students stated strongly agree and neutral with it and $67 \%$ of Indonesian students stated agree with it. For statement 2, 57\% of Malaysian lecturers stated agree with that statement and 50\% of Indonesian lecturers stated that strongly agree with it, whereas $56 \%$ of Malaysian students stated agree with it and $67 \%$ of Indonesian students stated agree with it. For statement 3, 71\% of Malaysian lecturers stated agree with that statement and 50\% of Indonesian lecturers stated that strongly agree with it, whereas $56 \%$ of Malaysian students stated strongly agree with it and $46 \%$ of Indonesian students stated agree with it. For statement 4, 71\% of Malaysian lecturers stated agree with that statement and $67 \%$ of Indonesian lecturers stated that strongly agree with it, whereas $56 \%$ of Malaysian students stated agree with it and $58 \%$ of Indonesian students stated agree with it. For statement 5, 71\% of Malaysian lecturers stated agree with that statement and $67 \%$ of Indonesian lecturers stated strongly agree with it, whereas $50 \%$ of Malaysian students stated agree with it and $50 \%$ of Indonesian students stated agree with it. For statement 6, 57\% of Malaysian lecturers stated agree with that statement and 50\% of Indonesian lecturers stated neutral with it, whereas $39 \%$ of Malaysian students stated neutral with it and 54\% of Indonesian students stated neutral with it. For statement 7, 71\% of Malaysian lecturers stated agree with that statement and $50 \%$ of Indonesian lecturers stated agree with it, whereas $67 \%$ of Malaysian students stated neutral with it and 54\% of Indonesian students stated neutral with it. 


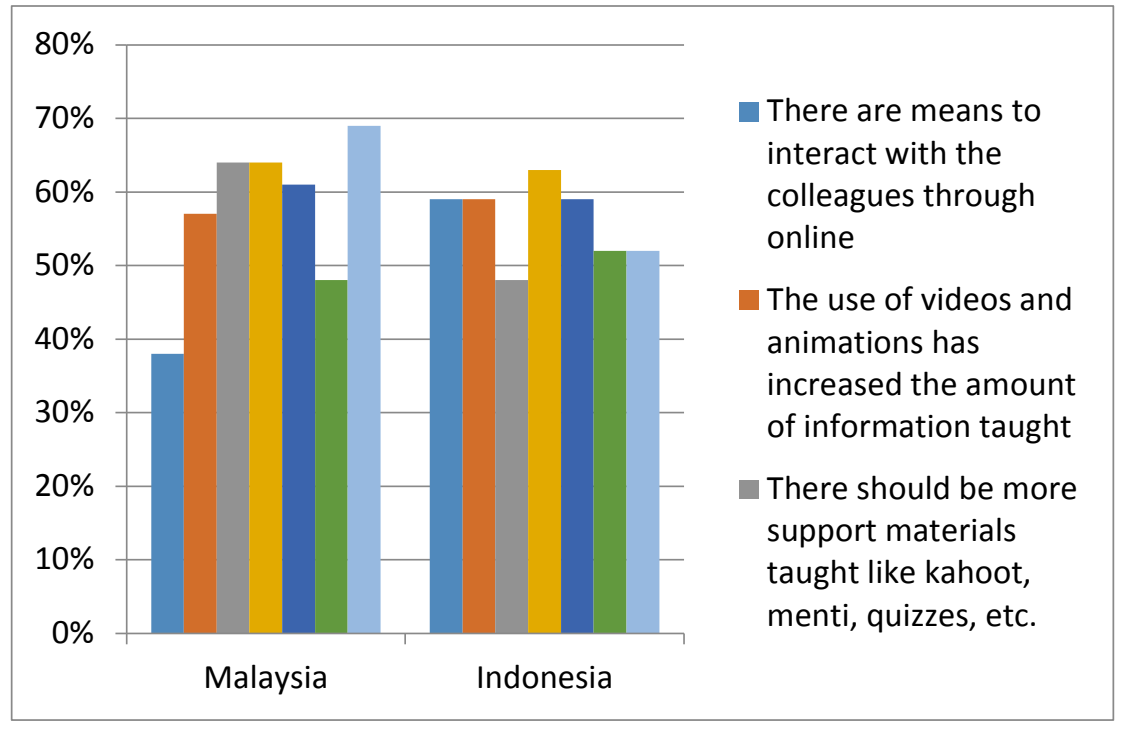

Figure 6. Comparison of Lecturers' and Students' Responses Using Online Learning in English Language Education (ELE) in Malaysia and Indonesia

Source: Personal data of excel

Figure 6 presents the lecturers' and students' responses using online learning in English Language Education (ELE) in Malaysia and Indonesia. In Malaysia, statement 1 (There are means to interact with the colleagues through online) has $38 \%$, in Indonesia it has 59\%. In Malaysia, statement 2 (The use of videos and animations has increased the amount of information taught) has $57 \%$, in Indonesia it has 59\%. In Malaysia, statement 3 (There should be more support materials taught like kahoot, menti, quizzes, etc.) has $64 \%$, in Indonesia it has $48 \%$. In Malaysia, statement 4 (There are means to interact with students through online) has 64\%, in Indonesia it has 63\%. In Malaysia, statement 5 (I can communicate with my students face to face) has $61 \%$, in Indonesia it has 59\%. In Malaysia, statement 6 (I am web proficient) has 48\%, in Indonesia it has 52\%. In Malaysia, statement 7 (I am web proficient) has 48\%, in Indonesia it has $52 \%$. Although the percentage is different for each point whether in Malaysia or Indonesia, the important thing is their responses are positive and they agree to the use of online learning.

\section{Discussion}

The use of online learning in the ELE during Covid-19 in Malaysia and Indonesia is effective to be conducted for students because they are able to access the knowledge anytime and anywhere. This is inline with the research conducted by Rizal et 
al. (2019) that learning in Malaysia and Indonesia has begun to integrate with ICT that implements online learning. Online learning prepares them for independent learning, lifelong learning and quality of learning. Malaysian and Indonesian lecturers and students prefer to use synchronous learning to the asynchronous one. There are a variety tools of synchronous and asynchronous learning which can be used. This research is a further research conducted by Jabeen \& Thomas (2015) that the students prefer classroom environment more than the online setting for language learning and the English skill which has a good effect according to them is speaking. In this research, it can be seen that the students and lecturers prefer to choose the synchronous learning method. Based on the data of this research, for synchronous learning, virtual meeting is in the first place (58\%) in Malaysia, whereas in Indonesia, phone call is in the first place (59\%). For asynchronous learning, blog is in the first place (54\%) in Malaysia and Indonesia. People in both countries use different type of tools in ELE learning process. They can use tools based on their needs during online learning as long as they can reach the target audience of teaching ELE. Online learning is effective for the teaching of English skills (listening, reading, writing and speaking). Based on this research, listening takes the first place based on Malaysian and Indonesian people. People in both countries agree that online learning gives a lot of benefit in the ELE process although the lecturers and the students are still adapting and trying to be web proficient because it needs time and process for online learning.

\section{CONCLUSION AND SUGGESTIONS}

\section{Conclusion}

During Covid-19 in Malaysia and Indonesia, the use of online learning in the ELE is effective to be conducted for students. Online learning is effective for teaching English language skills (listening, reading, writing and speaking). In online learning, many synchronous and asynchronous learning tools can be used by the lecturers to teach ELE students. People in Malaysia and Indonesia have different types of tools in ELE learning process. However, the lecturers should master the tools in order to apply them maximally in teaching ELE and the students should also adapt and try to learn the tools well so that the target of ELE teaching and learning process can be reached. 


\section{Suggestion}

It is suggested that the lecturers and the students master synchronous and asynchronous learning tools in the ELE teaching and learning process in order that the outcomes can be achieved. Furthermore, the research about online learning can be conducted further in similar ways but in different countries to explore the online learning implemented in other countries in the scope of ELE.

\section{REFERENCES}

Amiti, F. (2020). Synchronous and Asynchronous E-Learning. 5(2), 11.

Jabeen, S. S., \& Thomas, A. J. (2015). Effectiveness of Online Language Learning. 5.

Kurnia, T. (2020). Analis: Malaysia Lockdown Akibat Corona COVID-19, Aksi Pemerintah Cepat dan Tegas. Retrieved on 27 March 2020 from https://www.liputan6.com/global/read/4212670

Means, B., Yukie, T., Murphy, R., \& Baki, M. (2013). The Effectiveness of Online and Blended Learning: A Meta-Analysis of the Empirical Literature. Teachers College Record, 115, 47.

Mulyono, H. (2020). Using Quipper As An Online Platform for Teaching and Learning English As A Foreign Language. 13.

Rizal, F., Jalinus, N., Syahril, Sukardi, Zaus, M. A., Wulansari, R. E., \& Nabawi, R. A. (2019). Comparison of ICT Using in Learning between Indonesia and Malaysia. Journal of Physics: Conference Series, 1387, 012133. https://doi.org/10.1088/1742-6596/1387/1/012133

Rudestam, K. E., \& Schoenholtz-Read, J. (2010). The Flourishing of Adult Online Education. 28.

Son, J. Bae. (2011). Online Tools for Language Teaching. The Electronic Journal for English as a Second Language, 15(1), 12.

Wong, L. (2013). Student engagement with online resources and its impact on learning outcomes. Journal of Information Technology Education: Innovations in Practice, 12, 129-146. Retrieved from http://www.jite.org/documents/Vol12/JITEv12IIPp129-146Wong\%20FT116.pdf

Yale Centre for Language Study. (2015). Online Teaching Tools and Resources retrieved on 20 March 2015 from: http://cls.yale.edu/online-teachingtoolsresources. 